\title{
Possibilities of Large Gold Deposit Origin During the Mesozoic Stage of Ore Formation (East Siberian Platform)
}

\author{
Zinaida S. Nikiforova* \\ Diamond and Precious Metal Geology Institute SB RAS \\ 39 Lenina, Yakutsk, Republic of Sakha (Yakutia), 677000, Russia
}

Received 09.07.2017, received in revised form 18.09.2017, accepted 26.10.2017

Identification of gold deposits in the East Siberian platform is problematic, because the studied area is overlain by thick cover of $\mathrm{Mz}-\mathrm{Kz}$ deposits, where traditional exploration methods are ineffective. Thereby, it became necessary to study typomorphic properties of placer gold, as long as this research complex contains important information about endogenic ore formation. Study of placer gold typomorphism is a challenge for the development of mineralogic criteria of identification of types of ore sources and justification of large gold deposit prediction in the studied area. Result summary of the study of placer gold typomorphic features and analysis of the gold distribution allowed identifying two types of gold for the first time (I-type gold and II-type gold) with specific indicator signs, corresponding to two types of ore formation - Precambrian and Mesozoic. Analysis of geology evolution and result summary of the study of II-type gold typomorphic features suggest formation of large Mesozoic gold deposits, spatially confined to deep faults, or to occurred volcanic activity of andesite-dacite composition in the zones of intracontinental paleorifts. Comparison of mineralogic-geochemical features of placer gold and regularities of its distribution with gold of the North-American platform, and features of geology evolution of these regions allowed predicting formation of large $\mathrm{Mz}-\mathrm{Kz}$ deposits of gold-sulfidequartz association (Karlin type) - in the Molodo-Popigay fault system (Udzhinsky paleorift), Kuranakh type - in conjuction zone of the Urinsky anticlinorium with the north-eastern part of the Baikal-Patom thrust belt and gold-silver association (Cripple-Creek type) within the Kempenday dislocation zone (Viluy paleorift).

Keywords: Native gold mineralogy, mineralogic-geochemical features of placer gold, indicator signs, gold occurrence, primary sources, ore sources types, gold deposits, geologic-structural analysis, platform, deep faults, paleorifts.

Citation: Nikiforova Z.S. Possibilities of large gold deposit origin during the mesozoic stage of ore formation (east Siberian platform), J. Sib. Fed. Univ. Eng. technol., 2017, 10(7), 908-921. DOI: 10.17516/1999-494X-2017-10-7-908-921.

(c) Siberian Federal University. All rights reserved

* Corresponding author E-mail address: znikiforova@yandex.ru 


\title{
О возможности формирования
}

\section{крупных золоторудных месторождений мезозойского этапа рудообразования (восток Сибирской платформы)}

\section{3.С. Никифорова}

Институт геологии алмаза и благородных металлов СО РАН Россия, 677000, Республика Саха (Якутия), Якутск, пр. Ленина, 39

\begin{abstract}
Проблема выявления золоторудных месторождений востока Сибирской платформы состоит в том, что исследуемая территория перекрыта мощным чехлом $\mathrm{Mz}-\mathrm{Kz}$-отложений, где традиционные методы их поиска не эффективны. В связи с этим возникла необходимость изучения типоморфных свойств россыпного золота, поскольку этот комплекс исследований несет в себе важнейшую информачию об эндогенном рудообразовании. Изучение типоморфизма россыпного золота - актуальная задача для разработки минералогических критериев выявления формационных типов рудных источников и обоснования прогнозирования крупных месторождений золота в исследуемом регионе. Обобщение результатов изучения типоморфных особенностей россыпного золота и анализа закономерности его размещения позволило впервые выделить два типа золота (золото I типа, золото II типа) с определенными индикаторными признаками, соответствующих двум этапам рудообразования докембрийскому и мезозойскому. Анализ развития геологии и результаты изучения типоморфных особенностей золота II типа дают основание предполагать формирование крупных мезозойских золоторудных месторождений, пространственно приуроченных либо к глубинным разломам, либо к проявленной вулканической деятельности андезит-дацитового состава в зонах внутриконтинентальных палеорифтов. Сопоставление минералогогеохимических особенностей россыпного золота и закономерности его распределения $c$ золотом Северо-Американской платформы, а также с особенностями развития геологии этих регионов позволило впервые прогнозировать формирование крупных $\mathrm{Mz}-\mathrm{Kz}$-месторождений золото сульфидно-квариевой формачии типа Карлин в Молодо-Попигайской системе разломов (Уджинский палеорифт), типа Куранах в зоне сочленения Уринского антиклинория с северовосточной частью Байкало-Патомского надвигового пояса и золотосеребряной формации типа Крипл-Крик в пределах Кемпендяйских дислокаций (Вилюйский палеорифт).
\end{abstract}

Ключевые слова: минералогия самородного золота, минералого-геохимические особенности россыпного золота, индикаторные признаки, золоторудное проявление, коренные источники, формационные типы, золоторудные месторождения, геолого-структурный анализ, платформа, глубинные разломы, палеорифты.

Россыпная золотоносность на востоке Сибирской платформы установлена еще в начале XX в., но до сих пор не обнаружены крупные россыпи золота и не выявлены коренные источники, послужившие образованию столь обширного ореола рассеяния россыпного золота (рис. 1).

Проблема выявления коренных источников золота в данном регионе состоит в том, что исследуемая территория перекрыта мощным чехлом Mz-Kz-отложений, где традиционные методы поиска рудных месторождений золота не эффективны. В связи с этим возникла необходимость изучения типоморфных свойств россыпного золота, поскольку этот комплекс исследований несет в себе важнейшую информацию об эндогенном рудообразовании. Поэтому изучение типоморфизма золота - важная задача для выявления формационных типов коренных источ- 


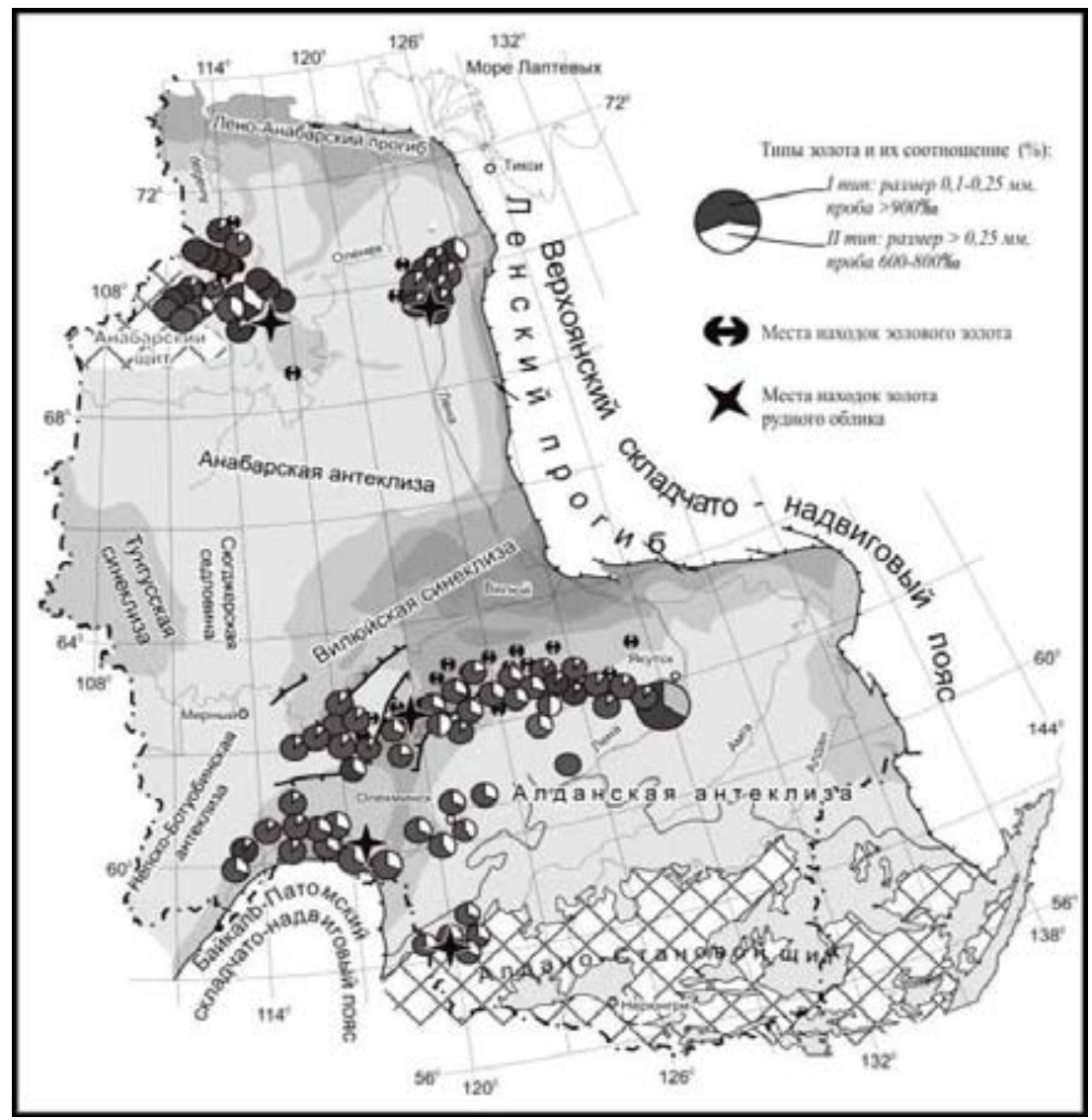

Рис. 1. Схема распространения россыпного золота разных типов на востоке Сибирской платформы Fig. 1. Map of placer gold of different types in the East Siberian platform

ников и разработки минералогических критериев прогнозной оценки рудной золотоносности докембрийского и мезозойского этапов рудообразования. Актуальность исследований заключается в обосновании прогнозирования крупных месторождений золота на востоке Сибирской платформы, пространственно приуроченных к древним выходам фундамента и внутриконтинентальным палеорифтам.

Существует множество точек зрения о рудных источниках золота востока Сибирской платформы, рассмотрим только основные (табл. 1). В.И. Тимофеев [1], Ю.Н. Трушков и др. [2], Б.Р. Шпунт и др. [3], а позднее В.А. Михайлов [4], анализируя историю геологического развития данного региона, высказали мнение об образовании коренных источников не только в докембрийский, но и в мезозойский этап рудообразования. В.Н. Зверев [5], Б.Р. Шпунт [3], И.Н. Истомин и В.М. Мишнин [6] и другие формирование частичной коренной золотоносности связали с широко проявленным базитовым магматизмом различного возраста.

Обобщение результатов изучения типоморфных особенностей россыпного золота и анализа закономерности его размещения в восточной части Сибирской платформы на территории Лено-Анабарского, Лено-Вилюйского междуречий и бассейна Средней Лены дали основание выделить два типа золота с определенными индикаторными признаками, соответствующими 
Таблица 1. Предполагаемые типы золоторудных проявлений, по данным различных исследователей (восток Сибирской платформы)

Table 1. Estimated types of gold occurrences according to different researchers (East Siberian platform)

\begin{tabular}{|c|c|c|}
\hline № & Коренные источники & Авторы \\
\hline 1 & $\begin{array}{l}\text { Сульфидизированные метаморфические породы } \\
\text { AR, приуроченные к минерализованным зонам } \\
\text { дробления древних выходов фундамента с } \\
\text { содержанием Au до } 2,7 \text { г/т }\end{array}$ & $\begin{array}{l}\text { Рожков и др., 1936; Рабкин, 1952; Тимофеев, } \\
\text { 1965; Шпунт и др.,1976; Толстов, 2002; } \\
\text { Смелов и др., 2004; Кравченко и др., } 2010\end{array}$ \\
\hline 2 & $\begin{array}{l}\text { Золотоносные архейские железистые кварциты с } \\
\text { содержанием Au 0,6 г/т }\end{array}$ & $\begin{array}{l}\text { Родионов, Блажкун, 1965; Кассандров, } \\
\text { Маринич, } 1979\end{array}$ \\
\hline 3 & $\begin{array}{l}\text { Кварц-карбонатные жилы } \mathrm{PR}_{1} \text { с содержанием } \mathrm{Au} \\
\text { до } 2 \text { г/т }\end{array}$ & $\begin{array}{l}\text { Левин, 1958; Петров, 1961; Тимофеев, 1965, } \\
\text { 1968; Трушков и др., 1975; Шпунт и др., } 1976\end{array}$ \\
\hline 4 & $\begin{array}{l}\text { Пиритизированные траппы с содержанием Au } \\
0,8 \text { г/т }\end{array}$ & $\begin{array}{l}\text { Обручев, 1923; Зверев, 1925; Родионов, 1961; } \\
\text { Еловских, 1969; Масайтис и др., } 1969\end{array}$ \\
\hline 5 & $\begin{array}{l}\text { Лимонитизированные, брекчированные породы } \\
\text { кембрия и мезозоя вблизи даек основного и } \\
\text { кислого состава, локализованные в пределах зон } \\
\text { тектонических нарушений, с содержанием } \mathrm{Au} \\
\text { до } 1,5 \text { г/т }\end{array}$ & $\begin{array}{l}\text { Коробков, Степанов 1963; Наварнов, } \\
\text { Шаталов, 1964; Фишер, Самохвалов, 1964; } \\
\text { Иванов и др., 1965; Михайлов, Филатов, } \\
\text { 1966; Дукарт и др., 1966; Блажкун, 1967; } \\
\text { Чумак и др., 1967; Еловских, 1967; Огиенко и } \\
\text { др., 1969; Шпунт, 1970; Тимофеев и др., 1970; } \\
\text { Трушков и др., 1975; Петров, } 1978\end{array}$ \\
\hline 6 & $\begin{array}{l}\text { Кварц-кальцитовые, кварц-баритовые } \\
\text { и пиритовые жилы, а также сидериты } \\
\text { гидротермального происхождения в меловых } \\
\text { и юрских отложениях в зоне Кемпендяйской } \\
\text { дислокации и в долине р. Вилюй с содержанием } \\
\mathrm{Au} \text { до } 1,4 \text { г/т }\end{array}$ & $\begin{array}{l}\text { Ченцов, 1960; Охлопков, 1962; Ганин, 1965; } \\
\text { Выриков и др., 1965; } \\
\text { Тимофеев, 1965; Кирина, 1966; Филатов, } \\
\text { 1967; Выриков, 1968; } \\
\text { Киселев, 1970; Бадарханов и др., } 1977\end{array}$ \\
\hline
\end{tabular}

двум этапам рудообразования - докембрийскому и мезозойскому (табл. 2, 3). Анализ закономерности распределения золота двух типов и сопоставление с геологией развития региона позволили выявить, что I тип золота образует широкий ореол рассеяния в обрамлении выходов фундамента и связан с докембрийским этапом рудообразования, а II тип золота распространен локально, приурочен к внутриконтинентальным палеорифтам и сформирован в мезозойский этап рудообразования [7]. В данной статье на основе изучения типоморфизма россыпного золота II типа будет сделан прогноз на выявление формационных типов золоторудных месторождений мезозойского этапа рудообразования.

Золото II типа (мезозойского этапа рудообразования) обнаружено в бассейнах рек ЛеноАнабарского (Эекит, Анабар, Эбелях) и в истоках рек Лено-Вилюйского междуречий (Кемпендяй, Намана, Тонгуо, Чебыда, Кенкеме и др.), а также в бассейне Средней Лены (Бол. Патом, Торго, Токко и др.). Данное золото пространственно приурочено к внутриконтинентальным палеорифтам: Уджинскому - на северо-востоке и Вилюйскому - на юго-востоке Сибирской платформы. По мнению Е.Е. Милановского [8], древние рифтовые зоны востока Сибирской платформы неоднократно были регенерированы в мезо-кайнозойское время, что, вероятно, способствовало формированию золоторудных месторождений мезозойского возраста. К рифтовой зоне он относит Уджинский авлакоген, развивавшийся с рифея до мезозоя включительно. По его предположению, образование инверсионной складчатой структуры 


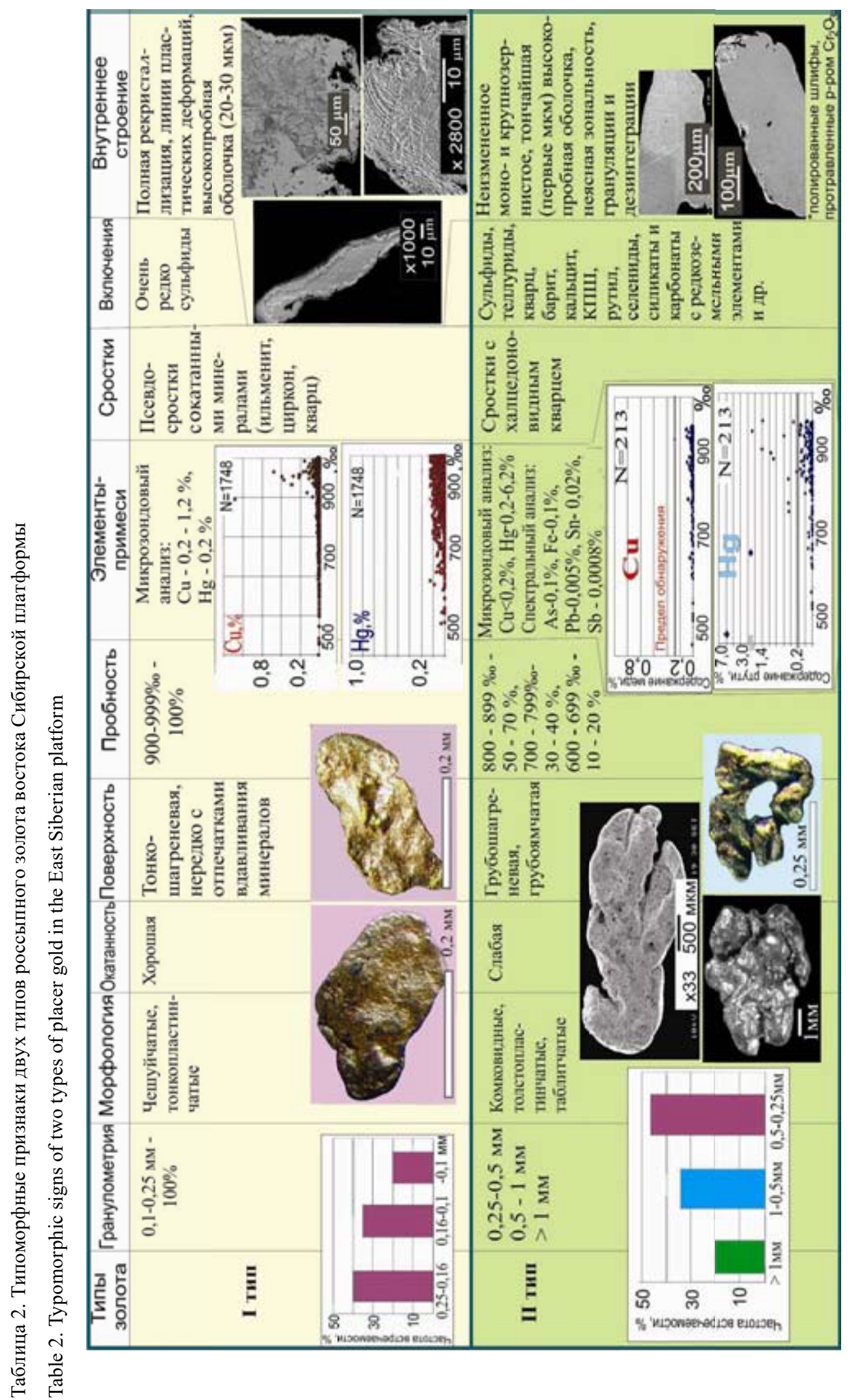


Таблица 3. Индикаторные признаки россыпного золота рудных формаций мезозойского этапа рудообразования

Table 3. Indicators of placer gold of mineral types of the Mesozoic stage of ore formation

\begin{tabular}{|c|c|c|c|c|c|c|}
\hline \multirow{2}{*}{$\begin{array}{c}\text { Типы } \\
\text { золото- } \\
\text { рудных } \\
\text { формаций }\end{array}$} & \multicolumn{6}{|c|}{ Характеристика россыпого золота } \\
\hline & $\begin{array}{c}\text { Грануло- } \\
\text { метрия (мм) }\end{array}$ & Форма & $\begin{array}{c}\text { Пробность } \\
(\%)\end{array}$ & $\begin{array}{c}\text { Элементы- } \\
\text { примеси }\end{array}$ & $\begin{array}{c}\text { Микро- } \\
\text { включения }\end{array}$ & $\begin{array}{c}\text { Внутренние } \\
\text { структуры }\end{array}$ \\
\hline $\mathrm{Au}-\mathrm{Ag}$ & $-0,25-1-2>$ & $\begin{array}{l}\text { Пластинчатая, } \\
\text { таблитчатая, } \\
\text { комковидная }\end{array}$ & $<500-870$ & $\begin{array}{l}\mathrm{Ag} \text { до } 47,7 \% \text {, } \\
\mathrm{Hg} \text { до } 1,46 \% \text {, } \\
\mathrm{Pb} 20-90 \text { г/т, } \\
\mathrm{Zn} 110-170 \text { г/т, } \\
\text { As } 20-70 \text { г/т } \\
\text { (до } 1000 \text { г/т), } \\
\mathrm{Sb} 12-60 \text { г/т, } \\
\text { ед. Те } 40 \text { г/т } \\
\text { и др. }\end{array}$ & $\begin{array}{l}\text { Стронциевый } \\
\text { барит, } \\
\text { арсенопирит, } \\
\text { пирит, кварц, } \\
\text { адуляр, кальцит }\end{array}$ & $\begin{array}{l}\text { Наличие } \\
\text { двухфазного } \\
\text { золота, } \\
\text { мозговидное, } \\
\text { пористое строение }\end{array}$ \\
\hline $\begin{array}{l}\text { Золото } \\
\text { редко- } \\
\text { метальное }\end{array}$ & $\begin{array}{l}-0,25 ; \\
0,25-0,5>\end{array}$ & $\begin{array}{l}\text { Пластинчатая, } \\
\text { таблитчатая, } \\
\text { комковидная, } \\
\text { дендрито- } \\
\text { видная }\end{array}$ & $<400-990$ & $\begin{array}{l}\mathrm{Bi} 480 \Gamma / \mathrm{T}, \\
\mathrm{Fe} 1000 \Gamma / \mathrm{T}, \\
\mathrm{Cu} 1109 \Gamma / \mathrm{T}\end{array}$ & $\begin{array}{l}\text { Самородный } \\
\text { висмут, } \\
\text { мальдонит, } \\
\text { арсенопирит, } \\
\text { теллуриды } \\
\text { серебра }\end{array}$ & $\begin{array}{l}\text { Среднезернистые, } \\
\text { неяснозональные, } \\
\text { яснозональные }\end{array}$ \\
\hline Ag-S-Q & $-0,25-1-2>$ & $\begin{array}{l}\text { Пластинчатая, } \\
\text { таблитчатая, } \\
\text { комковидная }\end{array}$ & $750-999$ & $\mathrm{Hg}$ до $5 \%$ & $\begin{array}{l}\text { Пирит, } \\
\text { арсенопирит, } \\
\text { кальцит, } \\
\text { теллуриды, } \\
\text { минералы с } \\
\text { редкоземель- } \\
\text { ными } \\
\text { элементами }\end{array}$ & $\begin{array}{l}\text { Крупнозернистые, } \\
\text { среднезернистые, } \\
\text { неяснозональные }\end{array}$ \\
\hline
\end{tabular}

Примечание: элементы примеси $\mathrm{Ag}, \mathrm{Cu}, \mathrm{Hg}$ - микрозондовый анализ (\%), $\mathrm{Pb}, \mathrm{Zn}, \mathrm{As}, \mathrm{Sb}, \mathrm{Te}, \mathrm{Bi}, \mathrm{Fe}, \mathrm{Cu}-\mathrm{aToмно-}$ эмиссионный спектральный анализ (г/т).

Уринского антиклинория возникло на месте одноименного рифейского авлакогена. Кроме этого, В.И. Тимофеевым [1] и др., на основании анализа развития геологии Вилюйской синеклизы было высказано предположение, что формирование рудной золотоносности в активизированных зонах Вилюйской синеклизы (Кемпендяйская дислокация) пространственно сопряжено с верхнеюрско-нижнемеловым магматизмом. Позднее В.А. Михайлов [4], анализируя минералогические ассоциации шлихового ореола рассеяния и петрографический состав галечно-гравийного материала Лено-Вилюйского междуречья, пришел к выводу, что образование мезозойского золоторудного оруденения, видимо, связано с магматизмом кислого состава. Потенциальным источником рудоносных гидротерм, по его мнению, были флюидно-эксплозивные (ФЭС), проявленные проявленные в виде трубочных тел, а также минерализованные зоны разрывных нарушений, гидротермальные аргиллизиты и тела дайкового типа. Действительно, по данным геологов (Ганин, 1965; Выриков и др., 1965; Кирина, 1966 и др.), в зоне Кемпендяйской дислокации (Вилюйский палеорифт) мезозойская тектономагматическая активизация привела к формированию приразломных складчатых структур (Табасындская антиклиналь и 12 мелких складок), а также к проявлению вулканической деятельности кислого состава. В связи с этим нами выдвинуто предположение, что основная 
мезозойская золоторудная минерализация образовалась в результате широко проявленной тектоно-магматической деятельности в рифтовых зонах.

Итак, анализ развития геологии данного региона и результаты изучения типоморфных особенностей золота позволили впервые прогнозировать формирование крупных мезозойских золоторудных месторождений, пространственно приуроченных либо к глубинным разломам, либо к проявленной вулканической деятельности андезит-дацитового состава в зонах внутриконтинентальных палеорифтов (Вилюйский, Уджинский палеорифты).

В целом, на северо-востоке Сибирской платформы впервые прогнозируются месторождения, пространственно связанные с глубинными разломами типа Карлин в Молодо-Попигайской системе разломов, на юго-востоке в бассейне Средней Лены в устьях рек Бол. Патом и Каменка (Уринский антиклинорий) золоторудное месторождение типа Куранах, пространственно контролируемое глубинным Баппагайским разломом, неоднократно подновляемое в мезозойское время, и типа Крипл-Крик в зоне Кемпендяйских дислокаций Вилюйского внутриконтинентального палеорифта, образованное в результате вулканической деятельности андезитдацитового состава.

Пространственную связь золотого оруденения с глубинными разломами подтверждают также данные предшественников (Коробков, Степанов, 1963; Фишер, Самохвалов, 1964; Дукарт, 1966 и др.). Ими в бассейне Средней Лены в кембрийских брекчированных и лимонитизированных кварцево-кремнистых породах были обнаружены многочисленные золотоносные проявления, пространственно приуроченные к разрывным нарушениям. В этих золотоносных проявлениях исследователями установлено содержание золота от 0,1 до 1,5-2,0 г/т, возраст которых, по их мнению, среднепалеозойский. Однако М.В. Михайлов, В.Ф. Филатов (1966), основываясь на своих исследованиях, установили, что золоторудные образования вблизи интрузий и разломов имеют мезозойский возраст.

Месторождения, сформированные в результате проявления вулканической деятельности андезит-дацитового состава, прогнозируются во внутриконтинентальных палеорифтах (Уджинском и Вилюйском), где впервые предполагается формирование близповерхностных месторождений золотосеребряной формации. Свидетельством проявления мезозойской вулканической деятельности служат данные предшественников. В.И. Тимофеевым [1] высказано предположение, что формирование рудной золотоносности в активизированных зонах Вилюйской синеклизы (Кемпендяйская дислокация) пространственно связано с верхнеюрским-нижнемеловым магматизмом. Позднее В.А. Михайлов [4] и другие пришли к выводу, что образование мезозойского золоторудного оруденения связано с магматизмом кислого состава. Потенциальным источником рудоносных гидротерм, по их мнению, являлись флюидно-эксплозивные структуры (ФЭС) в виде трубочных тел, а также минерализованные зоны разрывных нарушений, гидротермальные аргиллизиты и тела дайкового типа. По мнению В.А. Михайлова [4], такие рудопроявления формировались в обрамлении блоковых выступов фундамента (Сунтарский и др.) и соляно-купольных структур Кемпендяйской дислокации.

Таким образом, на востоке Сибирской платформы впервые выделяются территории, перспективные на поиски крупных мезозойских золоторудных месторождений, либо пространственно приуроченных к глубинным разломам, либо связанных с вулканической деятельностью андезит-дацитового состава. 
Одним из таких перспективных объектов является участок р. Моргогор (правый приток р. Эбелях) (рис. 2). Предполагаемое золоторудное проявление (типа Карлин) находится в зоне метасоматитов палеозойских терригенных отложений Молодо-Попигайской системы разломов (Уджинский палеорифт). В долине р. Моргогор обнажаются кембрийские терригеннокарбонатные породы. Исследуемая территория приурочена к Молодо-Попигайской системе разломов, где заложение рек происходило в мезозойское время по тектоническим нарушениям. В долине р. Моргогор разрывные нарушения фиксируются по зонам брекчирования, ожелезнения и окварцевания, ширина которых составляет от 3 до 50 м. Изучение типоморфных признаков россыпного золота р. Моргогор позволило выявить на протяжении 25 км наличие золота рудного облика размером 1-2 - >2 мм. Судя по особенности распределения золота рудного облика, дифференциация металла не происходила как по крупности, морфологии и степени окатанности, так и по пробности. Золото рудного облика присутствует как в истоке, так и в

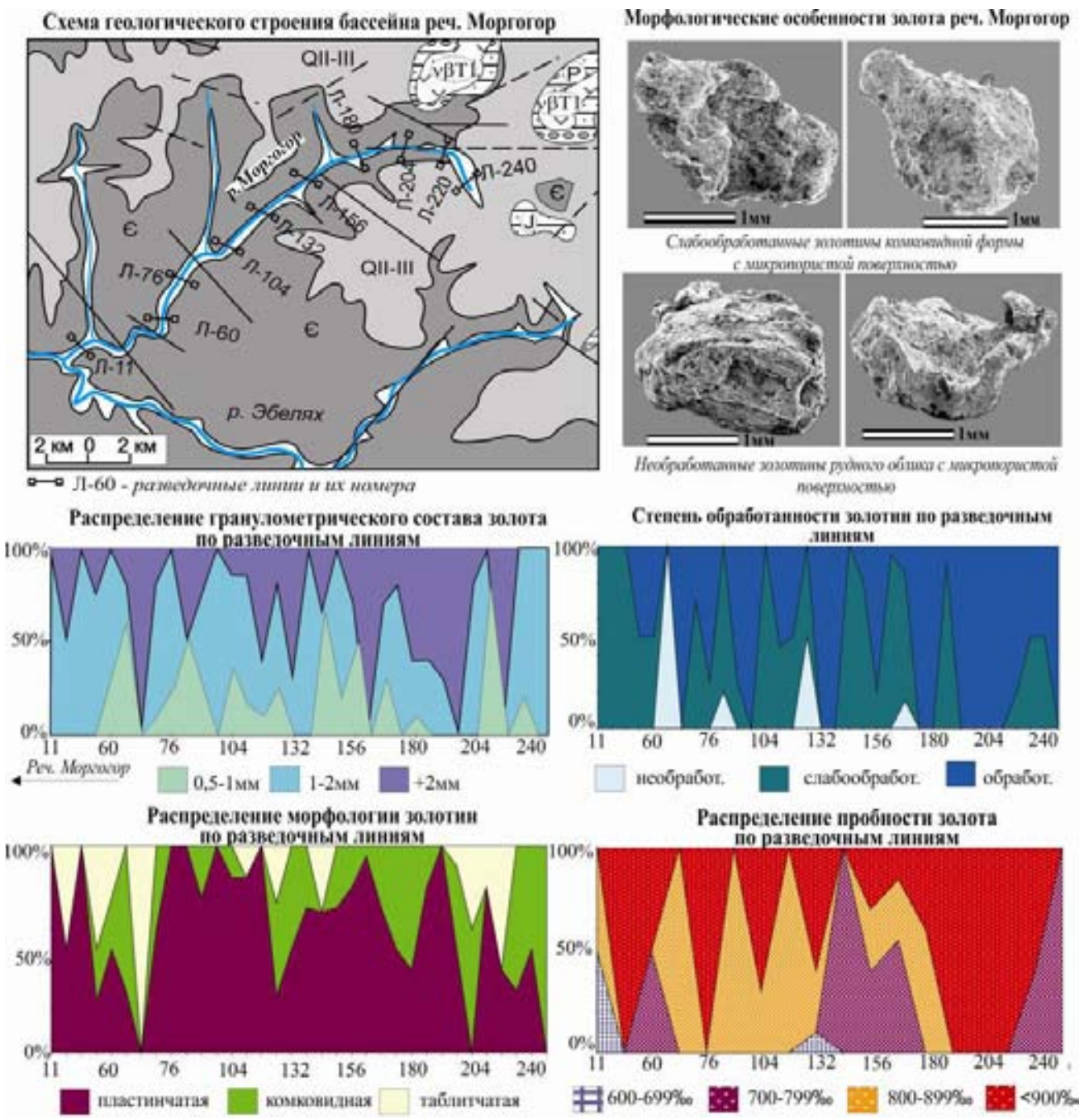

Рис. 2. Предполагаемое золоторудное месторождение в долине р. Моргогор (типа Карлин)

Fig. 2. Estimated gold deposit of Carlin type in the Morgogor river valley 
устье, что свидетельствует о его поступлении на протяжении всей долины из золоторудного источника, расположенного в самом русле реки [9].

Предполагаемое золоторудное проявление, видимо, пространственно связано с разрывными нарушениями мезозойского возраста и находится в зоне метасоматитов палеозойских терригенных отложений. По мнению М.М. Константинова [10], такие терригенно-карбонатные толщи платформенных областей, а именно зоны метасоматитов, пространственно приуроченные к глубинным разломам, заслуживают особого внимания для поисков месторождений карлинского типа.

Вторым перспективным объектом на выявление золоторудного источника считают устье рек Бол. Патом, Каменка (бассейн Средней Лены, Уринский антиклинорий). Долины устьев рек Бол. Патом и Каменка заложены по зоне глубинного Баппагайского разлома, который неоднократно подновлен в мезозойское время. Россыпное золото данного участка представлено пластинчатыми и комковидными формами, размером от пылевидного до $>0,25$ мм, пробностью 600-900 \%о, с содержанием $\mathrm{Hg}$ от 0,12 до 6,2 \%. В нем установлены микровключения кварца, кальцита, пирита, арсенопирита, теллуридов, селенидов и редкоземельных фосфатов (рис. 3). Наряду с этим, на данном объекте обнаружены (до 40 \%) губчатые хрупкие агрегаты, состоящие из сростков мелких частиц золота (до 0,01 мм) с гидрооксидами железа. Присутствие в аллювии такого хрупкого губчатого золота однозначно свидетельствует о близости коренного источника, пространственно приуроченного к зоне глубинного разлома. По результатам изучения минералого-геохимических особенностей россыпного золота выдвинуто предположение о формировании на данном объекте золоторудной минерализации типа Куранах. Доказательством этого положения послужило выявленное сходство типоморфных признаков россыпного золота рек Бол. Патома и Каменка (Уринский антиклинорий) с золотом Куранахского рудного поля, а именно наличие губчатых форм золота, присутствие в золотинах микровключений теллуридов, селенидов, фосфатов и силикатов с редкоземельными элементами и элементов-примесей $\mathrm{Hg}, \mathrm{Se}, \mathrm{Te}, \mathrm{Pb}, \mathrm{Fe}, \mathrm{Mn}, \mathrm{Cr}, \mathrm{Sn}, \mathrm{Cl}$, что послужило основанием прогнозировать коренные источники золото сульфидно-кварцевой формации. Выявленное сходство минералого-геохимических признаков россыпного золота Уринского антиклинория с золотом Куранахского рудного поля, и в первом приближении, их геологического развития позволяет прогнозировать на исследуемой территории золоторудные источники куранахского типа, характерные для месторождений Центрального Алдана.

Третий перспективный объект на поиски золоторудных источников выделяется в зоне Кемпедяйских дислокаций. Здесь на основе выявления индикаторных признаков россыпного золота, характерных для оруденений золотосеребряной формации, прогнозируется месторождение типа Крипл-Крик. О наличии золоторудных источников в зоне Кемпедяйских дислокаций свидетельствует обнаружение в аллювиальных отложениях Лено-Вилюйского междуречья (истоки рек Намана, Кемпендяй, Чебыда, Тонгуо, Ботомоу) крупного (до 2 мм) золота, которое не переносится на большие расстояния. Выявленные индикаторные признаки россыпного золота - низкая и средняя пробность (600-800 \%), широкий набор элементов-примесей ( $\mathrm{Pb}$, As, $\mathrm{Sb}, \mathrm{Zn}, \mathrm{Cu}$ и др.), неизмененное внутреннее строение (монозерна, крупнозернистое, двухфазное золото и др.) - характерны для оруденений золотосеребряной формации (рис. 4), что позволяет впервые выделять на исследуемой территории перспективный участок на поиски таких ме- 


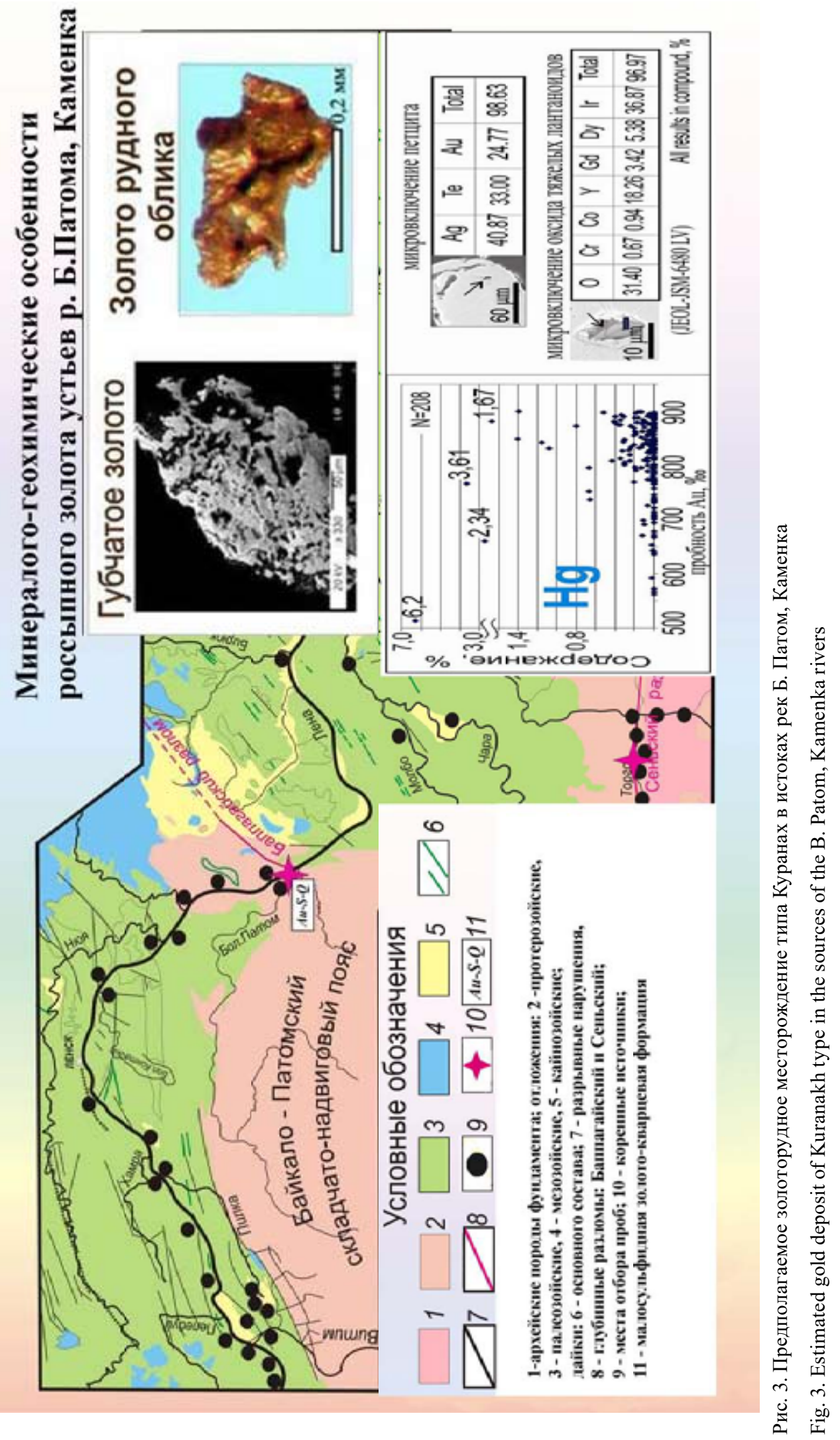




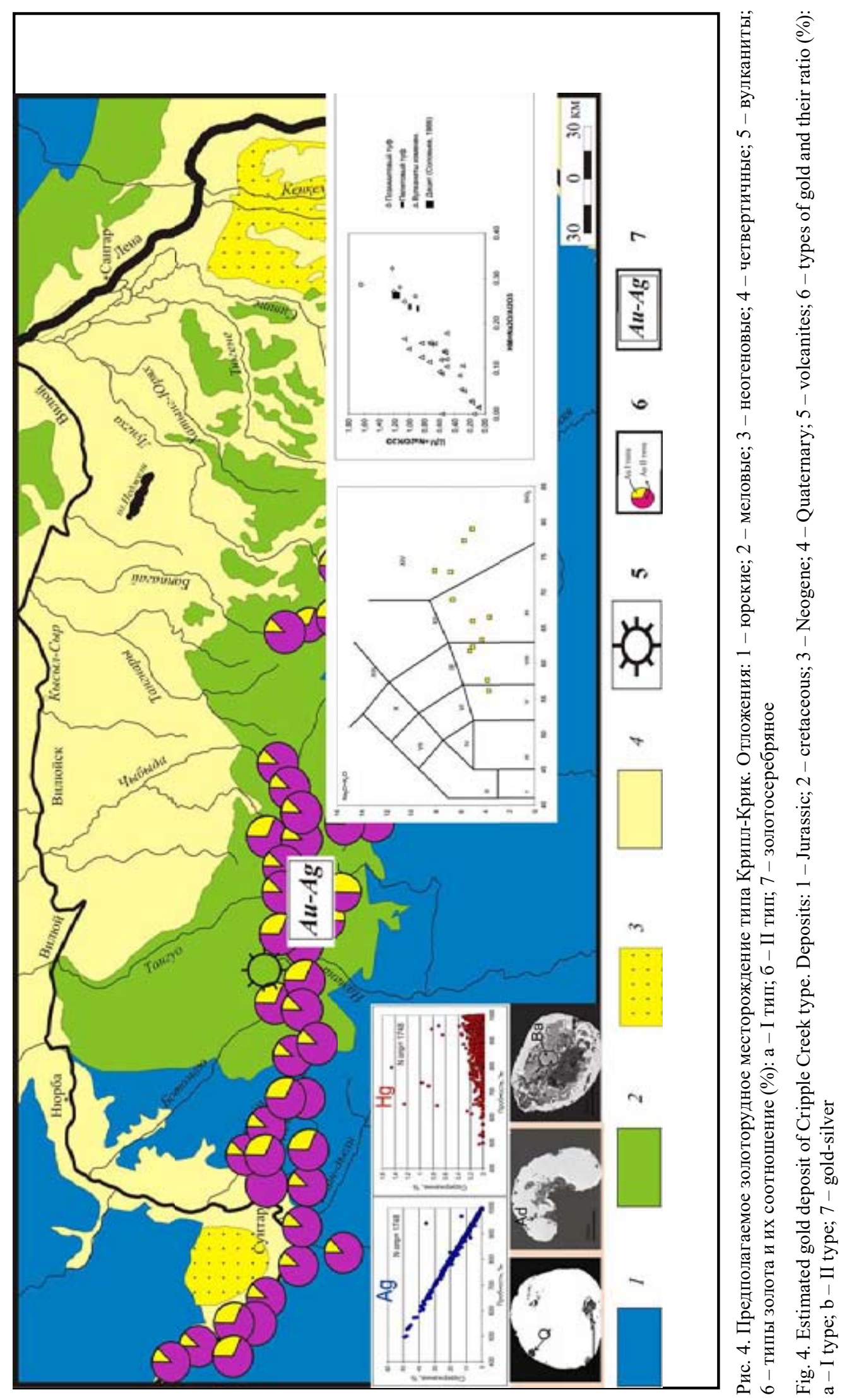


сторождений. Подтверждением этому служат также данные предшественников (Ченцов, 1960; Охлопков, 1962; Ганин, 1965; Выриков и др., 1965; Кирина, 1966; Киселев, 1970), ими в отложениях ранней юры и мела обнаружены золотоносные кварц-кальцит-баритовые жилы (Аu до 1,4 г/т). В этих жилах выявлены рудные минералы - пирит, магнетит, галенит, сфалерит, халькопирит. Более того, в русловом аллювии, наряду с аномально высокими содержаниями золота, ими установлено широкое распространение неокатанных зерен барита, гематита и халцедоновидного кварца, что дополнительно указывает на наличие коренного источника золотосеребряной формации. Происхождение таких рудопроявлений ими объяснялось процессами проявления кислого вулканизма раннеюрского и мелового возраста, что позднее подтвердилось и нашими исследованиями. Нами установлено, что максимальные концентрации россыпного золота пространственно совпадают с полями развития вулканических образований андезитдацитового состава, залегающих на нижнемеловых отложениях, найденных в зоне Кемпендяйских дислокаций [11]. По результатам спектрального анализа вулканитов обнаружено, что как в вулканитах, так и в низкосреднепробном золоте отчетливо прослеживается устойчивая $\mathrm{Ag}-\mathrm{Pb}-\mathrm{Zn}-\mathrm{Cu}$ геохимическая ассоциация, что позволило установить парагенетическую связь эпитермального золотосеребряного оруденения с вулканизмом и обосновать формирование в зоне Кемпендяйской дислокации месторождений золотосеребряной формации [12]. Сравнение геологического развития территории востока Сибирской платформы (Вилюйский палеорифт) с Северо-Американской (Скальный палеорифт), где аналогично во внутриконтинентальном рифте проявлена вулканическая деятельность андезит-дацитового состава и образовано крупное месторождение золотосеребряной формации Крипл-Крик, послужило основанием выдвинуть предположение о формировании такого же типа месторождений в зоне Кемпендяйских дислокаций.

Таким образом, сопоставление минералого-геохимических особенностей россыпного золота и закономерности его распределения с золотом Северо-Американской платформы, а также с особенностями развития геологии этих регионов позволило впервые предположить формирование крупных Mz-Kz-месторождений золотосульфидно-кварцевой формации типа Карлин в Молодо-Попигайской системе разломов (Уджинский палеорифт), типа Куранах в зоне сочленения Уринского антиклинория с северо-восточной частью Байкало-Патомского надвигового пояса, а золотосеребряной формации типа Крипл-Крик в пределах Кемпендяйских дислокаций (Вилюйский палеорифт) (рис. 5).

Статья подготовлена по результатам проекта «Стратегически важные виды минерально-сырьевых ресурсов и особенности геологического строения инвестиционнопривлекательных территорий Республики Саха (Якутия): металлогения, тектоника, магматизм, геоэкология, совериенствование поисковых и прогнозных технологий» Программы комплексных научных исследований в Республике Саха (Якутия), направленных на развитие её производительных сил и социальной сферы на 2016-2020 годы. 


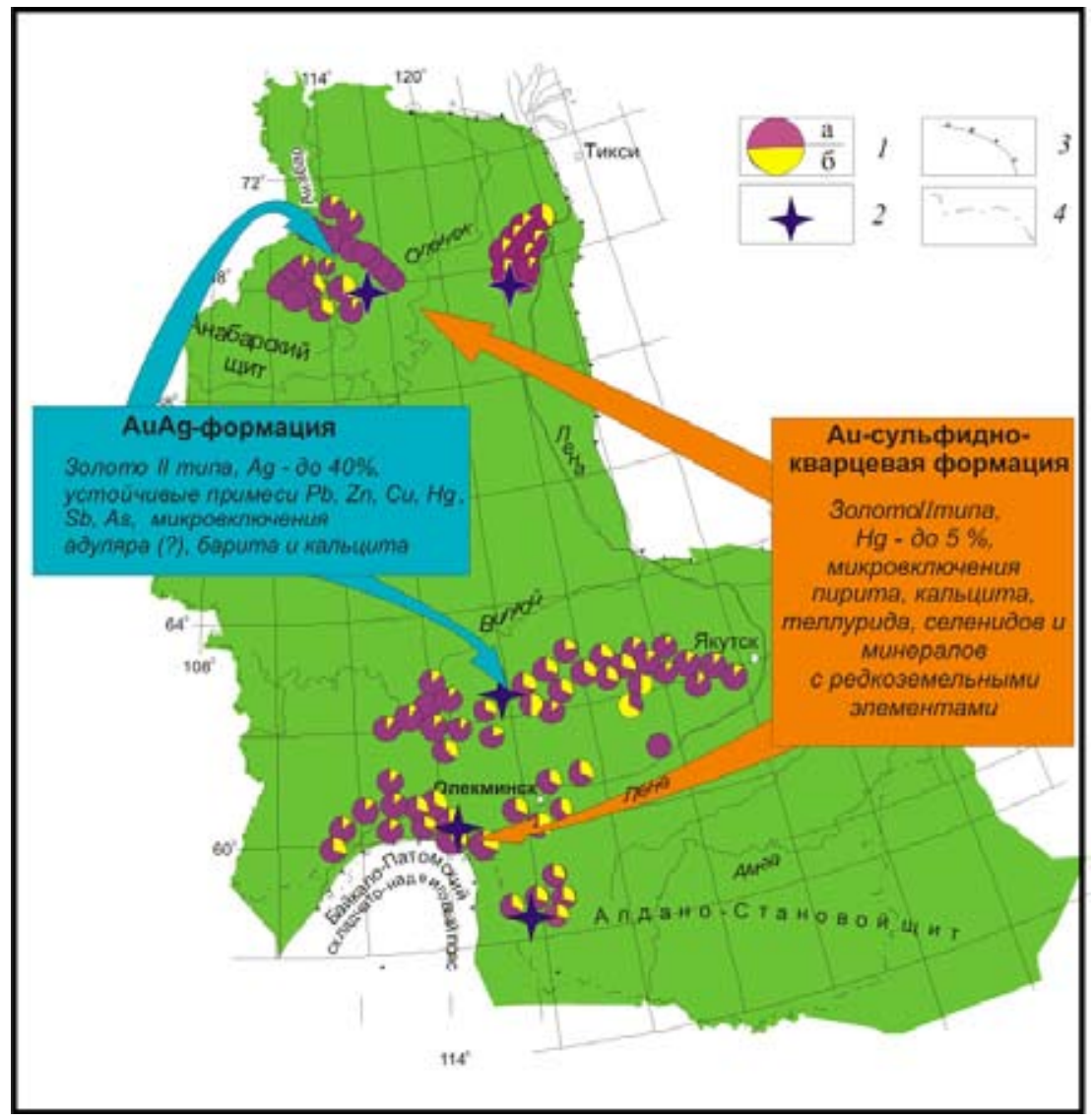

Рис. 5. Местонахождение прогнозируемых золоторудных месторождений типа Карлин и Крипл-Крик (восток Сибирской платформы): 1 - типы золота и их соотношения (\%): a - I тип: размер 0,1-0,25 мм, пробность $>900 \%$; б - II тип: размер > 0,25 мм, пробность 600-800 \%о; 2 - места обнаружения рудного золота; 3 - фронт фанерозойских орогенных поясов; 4 - граница Республика Саха (Якутия)

Fig. 5. Locations of predicted gold deposits of Carlin and Cripple Creek types (East Siberian platform): 1 - types of gold and their ratio (\%): a - I type; size 0,1-0,25 mm, fineness $>900 \%$; b - II type, size $>0,25 \mathrm{~mm}$, fineness $600-800 \%$; 2 - places of gold discovery; 3 - boundary of the Phanerozoic orogenic belts; 4 - border of the Republic of Sakha (Yakutia)

\section{Список литературы}

[1] Тимофеев В.И. О россыпной золотоносности бассейна р. Вилюй. Разведка и охрана недр, 1965, (6), 1-5. [Timofeev V.I. Placer gold content of the Vilyui river basin. Natural resource exploration and conservation, 1965, (6), 1-5 (in Russian)]

[2] Трушков Ю.Н., Избеков Э.Д., Томская А.И., Тимофеев В.И. Золотоносность Вилюйской синеклизы и ее обрамления. Новосибирск: Наука, 1975. 149 с. [Trushkov Y.N., Izbekov E.D., Tomskaya A.I., Timofeev V.I. Gold content of the Vilyui syneclise and its framing. Novosibirsk: Nauka, 1975. 149 p. (in Russian)]

[3] Шпунт Б.Р., Шамшина Э.А., Шаповалова И.Г. Докембрий Анабаро-Оленекского междуречья. Новосибирск: Наука, 1976. 142 с. [Shpunt B.R., Shamshina E.A., Shapovalova I.G. The Precambrian Anabar-Olenek interfluve. Novosibirsk: Nauka, 1976. 142 p. (in Russian)] 
[4] Михайлов В.А. Источники питания металлоносных отложений Вилюйской синеклизы: Автореф. дис. ... канд. геол.-мин. наук. ТГУ, Томск, 1990. 20 с. [Mikhailov V.A. Sources of supply of metalliferous deposits of the Vilyui syneclise: Author's abstract of dissertation of candidate of geologic-mineralogic sciences. TSU, Tomsk, 1990. 20 p. (in Russian)]

[5] Зверев В.Н. Условия золотоносности Вилюйского района. Известия Геолкома. 1925, 44 (5), 539-562. [Zverev V.N. Gold content condition of the Vilyui region. Izvestia Geolkoma. 1925, 44 (5), 539-562 p. (in Russian)]

[6] Истомин И.Н., Мишнин В.М. К проблеме поисков месторождений металлов платиновой группы в Якутии. Вестник Госкомгеологии РС (Я), 2003, 2 (5), 13-27. [Istomin I.N., Mishin V.M. Problem of exploration of platinum group metal deposits in Yakutia. Vestnik Goskomgeologii RS (Y), 2003, 2 (5), 13-17 p. (in Russian)]

[7] Никифорова 3.С., Герасимов Б.Б., Глушкова Е.Г., Каженкина А.Г. Золотоносность востока Сибирской платформы: россыпи-коренные источники. Геология рудных месторождений, 2013, 55 (4), 305-319. [Nikiforova Z.S., Gerasimov B.B., Glushkova E.G., Kazhenkina A.G. Gold content of the East Siberian platform: placers - primary sources. Geologia rudnukh mestorozhdeniy, 2013, 55 (4), 305-319 p. (in Russian)]

[8] Милановский Е.Е. Рифтогенез в истории Земли (рифтогенез на древних платформах). М., Недра, 1983. 280 с. [Milanovsky E.E. Riftogenesis in the Earth's history. (riftogenesis on ancient platforms). M., Nedra, 1983. 280 p. (in Russian)]

[9] Никифорова 3.С., Базилевская Р.В., Герасимов Б.Б. О находках рудного золота в бассейне р. Эбелях, северо-востока Сибирской платформы. Отечественная геология, 2006, (5), 48-52. [Nikiforova Z.S., Bazilevskaya R.V., Gerasimov B.B. Discoveries of lode gold in the Ebelyakh river basin, north-eastern Siberian platfro. Otechestvennaya geologia, 2006, (5), 48-52 p. (in Russian)]

[10] Константинов В.В. Золоторудные провиниии мира. М.: Научный мир, 2006. 355 с. [Konstantinov V.V. World gold provinces. M.: Nauchny mir, 2006. 355 p. (in Russian)]

[11] Никифорова 3.С., Ивенсен Г.В., Филиппов В.Е. Проявления вулканической деятельности на Лено-Вилюйском междуречье и ее связь с золотым оруденением. Международный Симпозиум Крупные магматические провинции Азии, мантийные плюмы и металлогения. Новосибирск. 2007, 182-184 [Ninkiforova Z.S., Ivensen G.V., Filippov V.Y. Manifestations of volcanic activity in the Lena-Vilyui interfluve and its association with gold mineralization. International sSymposium Large Igneous provinces of Asia, mantle plumes and metallogeny. Novosibirsk. 2007, 182-184 p. (in Russian)]

[12] Никифорова 3.С., Ивенсен Г.В. К вопросу формирования эпитермальных месторождений золота на территории Лено-Вилюйского междуречья. Рудогенез. Матер. международной конференции. Миасс, 2008, 203-206. [Nikiforova Z.S., Ivensen G.V. Matter of formation of epithermal deposits of gold in the territory of the Lena-Vilyui interfluve. Ore genesis. Materials of international conference. Miass, 2008, 203-206 p. (in Russian)] 